Quebec Cooperative Study

of Friedreich's Ataxia

\title{
Leucocyte Glutamate Dehydrogenase in Various Hereditary Ataxias
}

\author{
A. BARBEAU, M. CHARBONNEAU and T. CLOUTIER
}

SUMMARY: Leucocyte Glutamate Dehydrogenase (GDH) activity was measured in 44 patients with various forms of ataxia and 44 age and sex-matched normal controls. The only significant change found was a moderate decrease in activity in Freidreich's ataxia and a few patients with OPCA. This decreased activity is not primary to the disease but probably reflects a regulatory defect affecting mitochondrial membranes in these patients.

RESUMÉ: Nous avons mesurél'activité de la Glutamate deshydrogénase (GDH) leucocytaire chez 44 patients ataxiques et 44 témoins normaux apparillés pour l'âge et le sexe. La seule différence significative trouvée fut une diminution modérée des niveaux d'activité du GDH dans l'ataxie de Friedreich et quelques cas d'OPCA. Cette diminution dans l'activité enzymatique reflète probablement un défaut régulatoire touchant les membranes mitochondriales chez ces patients.
From the Department of Neurobiology, Clinical Research Institute of Montreal.

Reprint requests for the complete supplement on Friedreich's Ataxia (phase three) to: Dr. André Barbeau, Clinical Research lnstitute of Montreal, 110 Pine Ave. West, Montreal, Quebec, Canada H2W IR7.

\section{INTRODUCTION}

The investigation of Friedreich's ataxia carried out over the last few years has revealed low concentrations of glutamate, aspartate and/or GABA in various regions of the cerebellum and spinal cord (Robinson, 1968; Huxtable et al, 1979). Similar findings have been reported in olivo-pontocerebellar atrophies (Perry et al, 1977) and in neurological mutant mice with ataxia (McBride et al, 1976; RofflerTarlov and Sidman, 1978) or various other models of ataxia in animals produced by 3-acetyl-pyridine (Butterworth et al, 1978) or thiamine deficiency (Butterworth et al, 1979). Glutamate is formed, in part, from $\alpha$-ketoglutarate through the action of glutamate dehydrogenase (E.C.1.4.1.3) (GDH), a hexameric molecule with one type of polypeptide chain and no known isoenzymes (Nelson et al, 1977). Glutamate may serve a role as a putative neurotransmitter in various areas of the CNS, such as the cerebellum, the brainstem and the spinal cord (Davidson, 1978; Graham and Aprison, 1969). A similar role can possibly be assigned to the other acidic amino-acid, aspartate. Both substances usually have an excitatory function (Davidson, 1978). It was thus of importance to study the synthesis of glutamate in ataxic patients, in view of the low glutamate concentrations reported above. This report presents the results of an investigation of glutamate dehydrogenase (GDH) in leukocytes of patients with Friedreich's ataxia and other forms of hereditary ataxias.

\section{SUBJECTS AND METHODS}

The studies were carried out in a total of 44 ataxic subjects and 44 age and sex-matched normal controls taken from Institute and laboratory personnel. Each patient was individually matched with his control before blood was drawn, and the two samples run through identical procedures on the same day. The 44 ataxic subjects included 22 patients with typical Friedreich's ataxia according to the criteria of Geoffroy et al (1976); 9 patients with the recessive spastic ataxia of Charlevoix-Saguenay (Bouchard et al, 1978); 8 with the dominantly inherited olivo-pontocerebellar atrophy (OPCA) of the Gaspé type (Wastiaux et al, 1978) and finally 5 recessive ataxias of undetermined classification, but with a slow course, little pes cavus or kyphoscoliosis. These may be variants of Friedreich's ataxia, or more likely a recessive form of Roussy-Levy syndrome.

GDH was determined in duplicate in leucocytes with a modification of the method of Schmidt (1974). In summary, this method implies collection of blood in EDTA and Dextran, centrifugation $(600 \mathrm{G})$ of the plasma and hemolysis of the pellet which is then washed 3 times with a saline $\mathrm{K}^{+}$-phosphate buffer at $\mathrm{pH} 7.4$; resuspension of $40 \mathrm{mg}$ of WBC into saline buffer for homogenization and sonication ( 3 times 15 seconds, $175 \mathrm{amps}$ ) on ice and further centrifugation $(12,000$ $\mathrm{G})$. The enzyme activity is determined using the $\alpha$-oxoglutarate to glutamate direction with the transformation of NADH to NAD being read fluometrically for 10 minutes at $340 \mathrm{~nm}$ at a final $\mathrm{pH}$ of 7.9. The incubation mixture contained triethanolamine buffer, $\mathrm{NaDH}(0.2 \mathrm{mM})$, ADP (1.0 $\mathrm{mM})$, ammonium acetate, $\mathrm{LDH}(2.0$ $\mathrm{u} / \mathrm{ml}$ ), unknown sample (175-225 $\mu \mathrm{g}$ proteins) and $\alpha$-ketoglutaric acid. Protein was measured with the method 
of Lowry et al (1951). In further experiments GDH activity was also measured with Triton X-100 used to disrupt the cells instead of sonication. Finally cultured fibroblasts obtained from 10 Friedreich's ataxia patients and 9 normal controls were also assayed from GDH activity. Results for GDH activity were expressed as $\mu \mathrm{M} / \mathrm{mg}$ protein $/ \mathrm{min}$. Statistical significance was calculated using Student's " $t$ " test for paired samples.

\section{RESULTS AND DISCUSSION}

\section{(a) Friedreich's ataxia:}

Leucocyte GDH activity was measured in 22 patients and their age and sex-matched controls. The results for the first 18 pairs are illustrated in Fig. 1. The same results were observed in the last 4 not illustrated. One notes a highly significant $(\mathrm{p}<0.001)$ decrease in the mean GDH activity in Friedreich's ataxia which is of the order of $23 \%$, but the two ranges overlap. It is thus impossible to use such GDH data for prediction or for diagnosis, and it is unlikely that a decrease of this magnitude would be a direct gene product.

\section{(b) Spastic ataxia of Charlevoix- Saguenay:}

Leucocyte GDH activity in this syndrome was only slightly decreased, barely reaching statistical significance with Student's paired $\tau$ test (Fig. 2). Again the range of values in patients clearly overlap those of the controls.

\section{(c) Olivo-ponto-cerebellar atrophy:}

In 8 patients with the Gaspé type of OPCA, dominantly inherited, most likely type I of Konigsmark and
Weiner (1970), the mean of the determinations was normal, even though two individual cases were below the normal range (Fig. 3). These two cases, moderately advanced in their disease, did not have GDH values as low as those reported by Plaitakis and collaborators (1980), however they were part of the same family as the others. It is now evident that, even biochemically, all OPCA families do not have the same defect.

(d) Non Friedreich Recessive ataxias:

The 5 cases of this entity studies all fell within the normal range of GDH activity (Fig. 3).

\section{(e) Overall results:}

As can be seen in the composite picture of Fig. 4, the only significant change in leucocyte GDH activity is

\section{LEUKOCYTE GLUTAMATE DEHYDROGENASE(GDH) ACTIVITY}

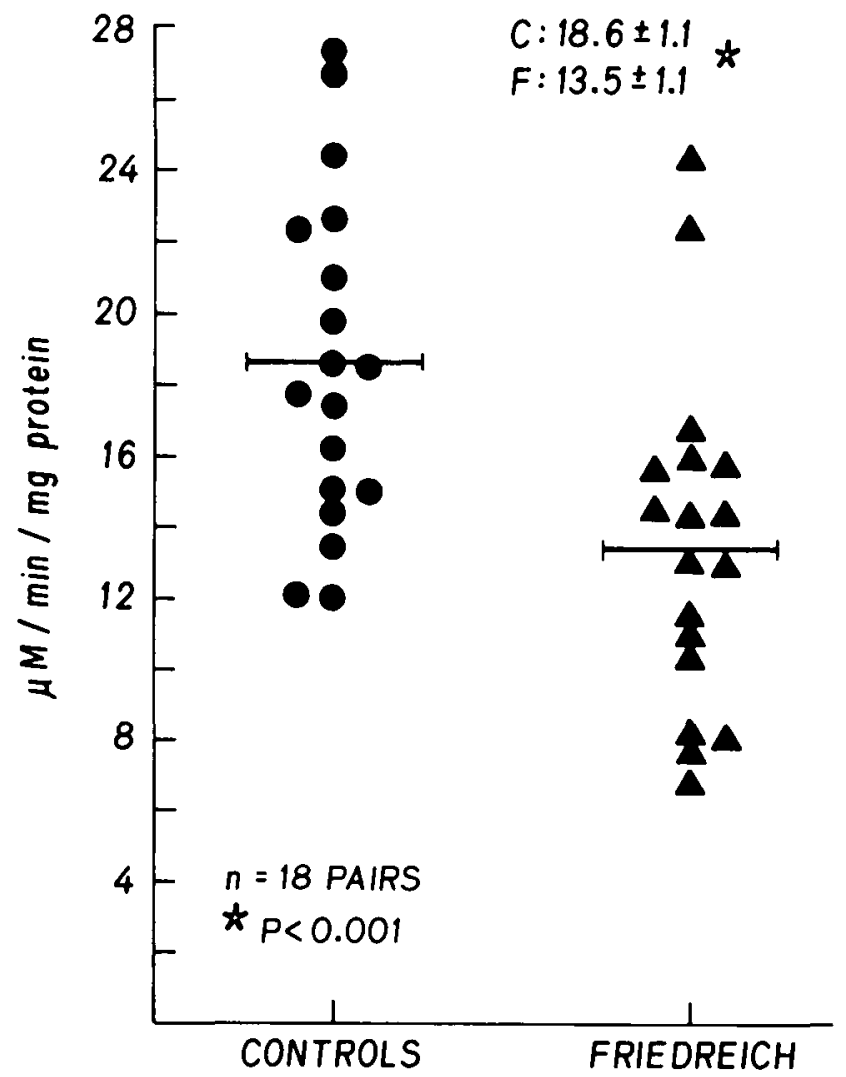

Figure I - Leucocyte Glutamate Dehydrogenase (GDH) activity in Friedreich's ataxia.

\section{LEUKOCYTE GLUTAMATE DEHYDROGENASE} IN SPASTIC ATAXIA

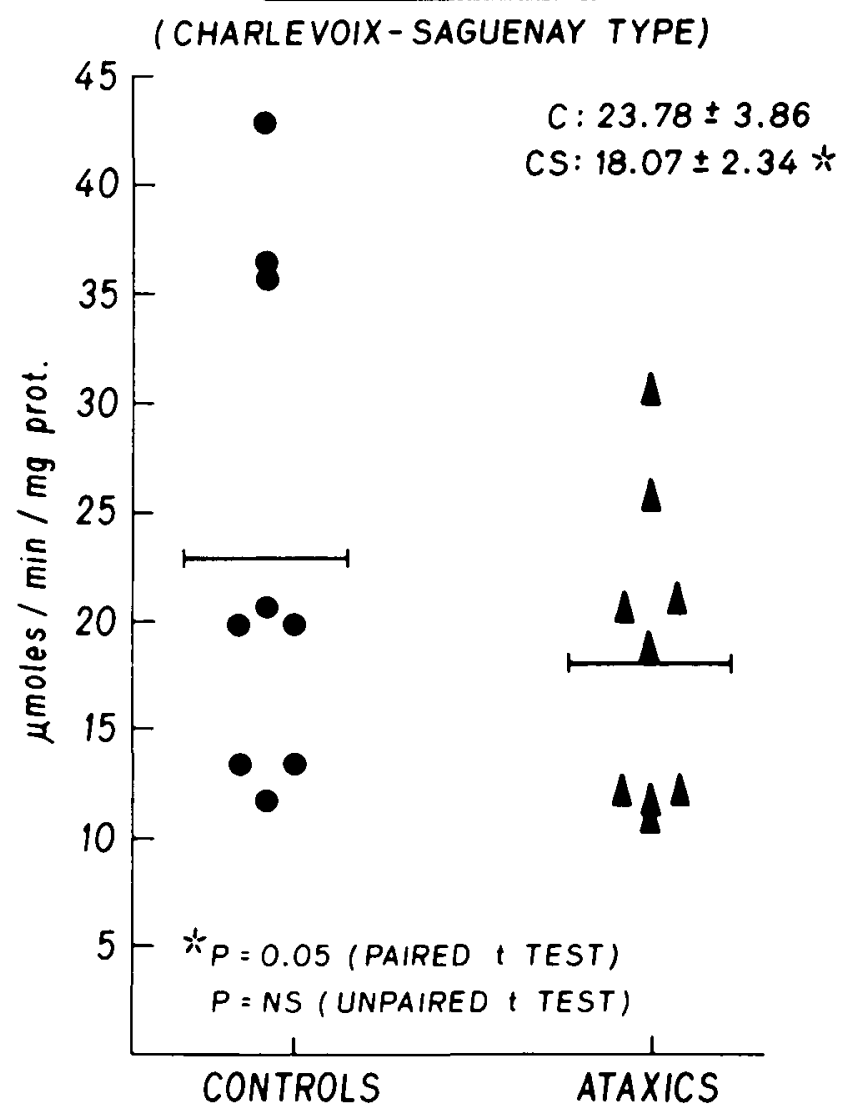

Figure 2 - Leucocyte Glutamate Dehydrogenase activity in Spastic Ataxia of the Charlevois-Saguenay type. 
LEUKOCYTE GLUTAMATE DEHYDROGENASE IN DOMINANT OPCA AND VARIOUS RECESSIVE ATAXIAS

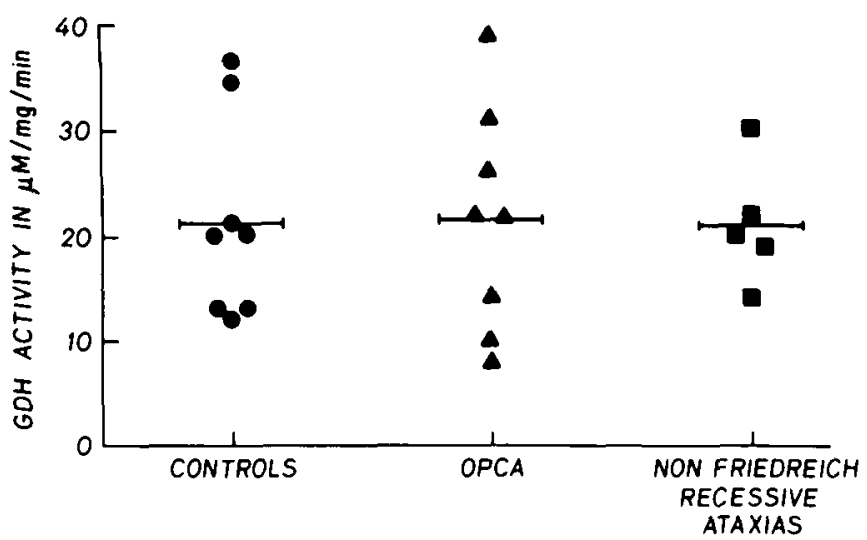

Figure 3 - Leucocyte Glutamate Dehydrogenase activity in dominant OPCA and various recessive ataxias.
LEUKOCYTE GLUTAMATE DEHYOROGENASE IN ATAXIA (MEAN I RANGE OF VALUES)

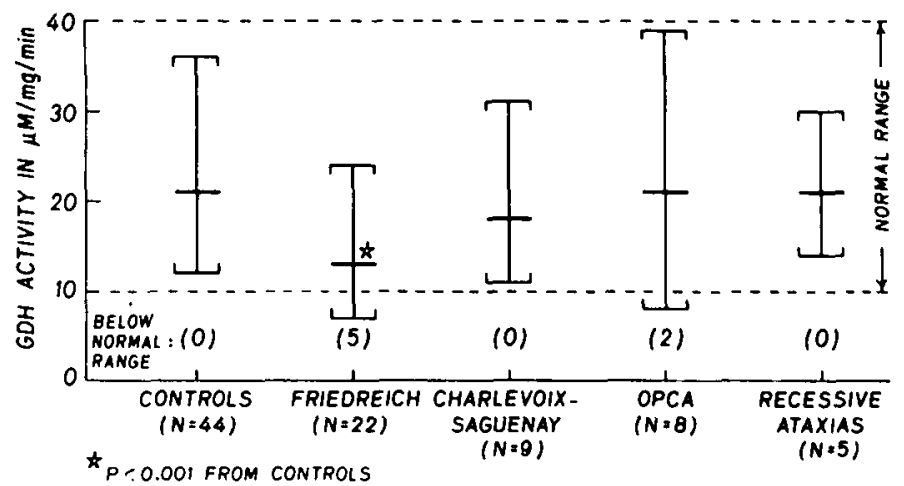

Figure 4 - Overall results of Leucocyte Glutamate Dehydrogenase activity studies in various forms of ataxia. The brackets indicate the range of values. The only significant difference is for Friedreich's ataxia. found in Friedreich's ataxia and the occasional dominant OPCA. However, we must again note that the decrease, although significant, is of low magnitude. It most likely does not reflect the primary gene defect, but is secondary to a regulatory defect in the functions of the Krebs cycle, or to a substrate deficit, such as the low glutamate pool found in these patients.

\section{(f) Methodology:}

Because preliminary results in Friedreich's ataxia cases from another laboratory did not seem to confirm the above findings, we repeated the experiment in 13 patient-control pairs using Triton X-100 instead of Sonication, to dislocate the cells. As can be seen in Fig. 5 the values obtained with Triton are higher in both groups. However the significant differences in total activity (Friedreich 31.78 \pm 1.64 $\mu \mathrm{M} / 21.5 \mathrm{mg}$ vs controls $39.67 \pm 2.19$ $\cdot M / 21.5 \mathrm{mg}, \mathrm{p}<0.00 \mathrm{l})$ and in specific activity (Friedreich $13.90 \pm 1.20$ $\mu \mathrm{m} / \mathrm{min} / \mathrm{mg}$ prot.; controls $20.55 \pm$ $2.37 \mu \mathrm{M} / \mathrm{min} / \mathrm{mg}$ prot. $\mathrm{p}<0.05$ ) now completely disappear (Total activity: Friedreich $70.56 \pm 4.23 \mu \mathrm{M} / 21.5 \mathrm{mg}$; controls $74.15 \pm 3.07 \mu \mathrm{M} / 21.5 \mathrm{mg}$; $\mathrm{p}=\mathrm{NS} ;$ Specific activity: Friedreich: $39.16 \pm 2.26 \mu \mathrm{M} / \mathrm{min} / \mathrm{mg}$ prot.; controls $41.51 \pm 2.09 \mu \mathrm{M} / \mathrm{min} / \mathrm{mg}$ prot., $\mathrm{P}=\mathrm{NS}$ ).

Thus, the method of disruption of the cell influences the results. This observation is further confirmed by the following experiment where the same sample was subjected, in separate aliquots, to one or 5 sonication periods or Triton X-100 at low and high concentrations (Fig. 6). It can be seen that augmenting the number of sonications, increases slightly the GDH activity in the supernatant, thus GDH released, but that the difference between control and Friedreich subjects persists. On the other hand this difference is completely abolished at

\section{TABLE 1}

Glutamate Dehydrogenase Activity in Fibroblasts $(\mu \mathrm{M} / \mathrm{min} / \mathrm{mg}$ mean \pm S.E.M. $)$

\begin{tabular}{lcc}
\hline & $\begin{array}{c}\text { CONTROLS } \\
(\mathrm{n}=9)\end{array}$ & $\begin{array}{c}\text { FRIEDREICH } \\
(\mathrm{n}=10)\end{array}$ \\
\hline SONICATION & $258.21 \pm 42.60$ & $263.07 \pm 31.65$ \\
TRITON & $192.10 \pm 21.98$ & $188.09 \pm 19.77$ \\
\hline
\end{tabular}

higher concentrations of Triton. From this experiment we conclude that Triton not only dislocates the cells better, but that its affinity for lipids may indicate that, in Friedreich's ataxia, the low GDH activity may be related to a lipid or fatty acid component of the mitochondrial membrane in abnormal concentration or of abnormal composition.

\section{(g) Fibroblasts:}

Finally in a preliminary experiment (Table 1) we were not able to demonstrate a significant decrease in GDH activity in fibroblasts from Friedreich's ataxia patients, using sonication or Triton. However, these results must be used with caution because of the wide range of values observed, as indicated by the high SEM.

\section{CONCLUSION}

In summary, we have demonstrated a significant, but low, decrease in GDH activity in leucocytes from patients with Friedreich's ataxia, but not in those with other forms of ataxia. This decrease is found when the cells are dislocated by sonication, but not after Triton, indicating that the regulatory defect affecting the enzyme activity may be related to a lipid or fatty acid component of the mitochondrial membrane, and that the primary defect in Friedreich's ataxia is not to be found in abnormalities of glutamate 


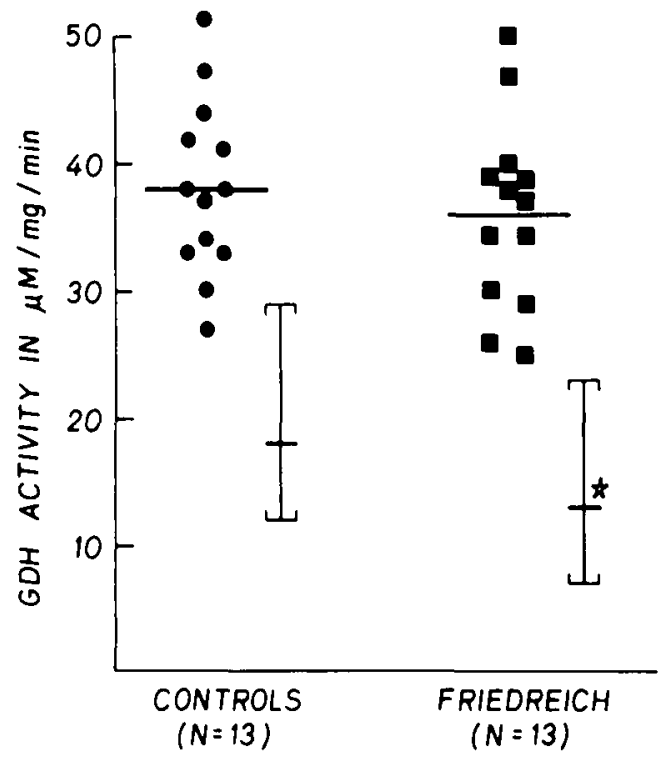

EH MEAN \pm RANGE (SONICATION)
Figure 5 - Leucocyte Glutamate Dehydrogenase activity in 13 Friedreich's ataxia patients using sonication (brackets) or Triton X-100 (dots and squares).

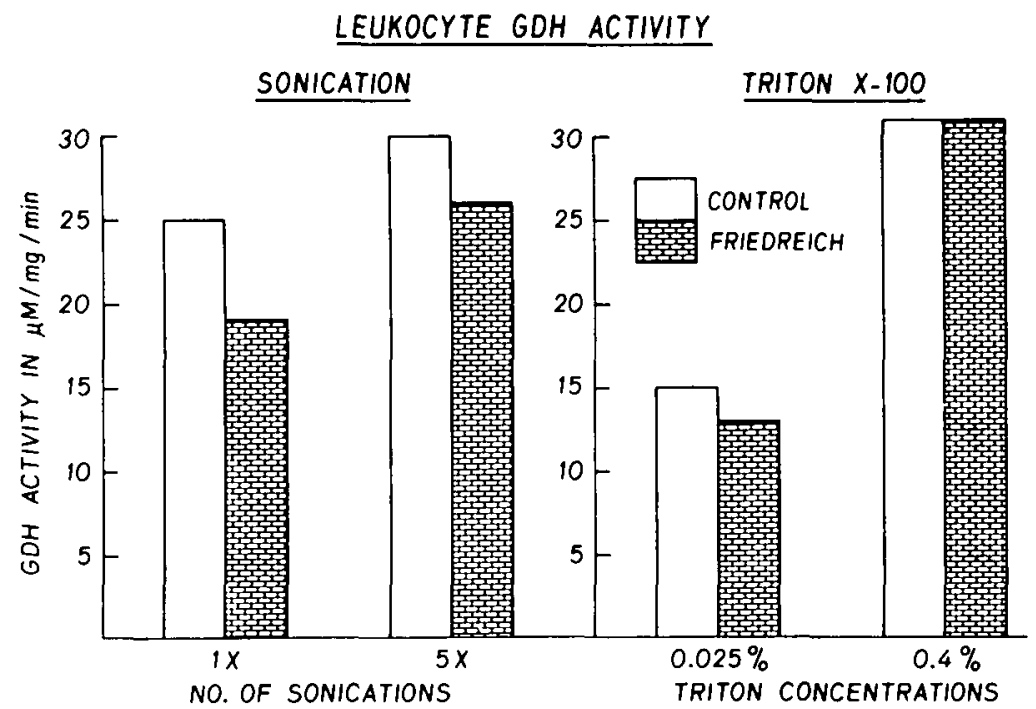

Figure 6 - Effect of repeated sonications or of increasing Triton concentrations upon Leucocyte GDH activity of patients with Friedreich's ataxia and of normal control subjects. dehydrogenase. However, the low values found in Friedreich's ataxia are compatible with the postulated energy deficit in this disease and with the observation of low glutamate concentrations in certain regions of the central nervous system.

\section{ACKNOWLEDGEMENTS}

These studies were supported by a grant from l'Association Canadienne de l'Ataxie de Friedreich. We would like to thank Miss D. Bédard RN for nursing assistance and Miss Diane Magnan for typing the manuscript.

\section{REFERENCES}

BOUCHARD, J.P., BARBEAU, A., BOUCHARD, R. and BOUCHARD, R.W. (1978). Autosomal recessive spastic ataxia of Charlevois-Saguenay. Can. J. Neurol. Sci., 5: 61-69.

BUTTER WORTH, R.F., HAMEL, E., LANDREVILLE, F. and BARBEAU, A. (1978). Cerebellar ataxia produced by 3acetyl pyridine in rat. Can. $\mathbf{J}$. Neurol. Sci., 5 : 131-133.

BUTTER WORTH, R.F., HAMEL, E., LANDREVILLE, F. and BARBEAU, A. (1979). Amino acid changes in thiaminedeficient encephalopathy: Some implications for the pathogenesis of Friedreich's Ataxia. Can. J. Neurol. Sci., 6: 217-222.
DAVIDSON, N. (1978). Neurotransmitter amino acids. London, Academic Press.

GEOFFROY, G., BARBEAU, A., BRETON, G., LEMIEUX, B., AUBE, M., LEGER, C. and BOUCHARD, J.P. (1976). Clinical description of Roentgenologic evaluation of patients with Friedreich's ataxia. Can. J. Neurol. Sci., 3: 279-286.

GRAHAM, L.T. and APRISON, M.H. (1969). Distribution of some enzymes associated with the metabolism of glutamate, aspartate, $\gamma$-amino butyrate and glutamine in cat spinal cord. J. Neurochem., 16: 559-566.

HUXTABLE, R., AZARI, J., REISINE, T., JOHNSON, P., YAMAMURA, H.I. and BARBEAU, A. (1979). Regional distribution of a mino acids in Friedreich's Ataxia brains. Can. J. Neurol. Sci., 6: 255-258.

KONIGSMARK, B.W. and WEINER, L.P. (1970). The olivopontocerebellar atrophies. A review. Medicine, 49: 227-241.

LOWRY, O.H., ROSENBROUGH, N.J., FERR, A.L. and RANDELL, R.J. (1951). Protein measurement with the Folin-phenol reagent. J. Biol. Chem., 193: 265-268.

McBRIDE, W.J., APRISON, M.H. and KUSANO, K. (1976). Contents of several amino acids in the cerebellum, brain stem and cerebrum of the 'staggerer', 'weaver' and 'nervous' neurologically mutant mice. J. Neurochem., 26: 867-870.

NELSON, R.L., POVEY, M.S, and HOPKINSON, D.A. (1977). Electrophoresis of human L-glutamate dehydrogenase: tissue distribution and preliminary population survey. Biochem. Genet., 15: 87-91.

PERRY, T.L., CURRIER, R.D., HANSEN, S. and MacLEAN, J. (1977). Aspartate-taurine imbalance in dominantly inherited olivopontocerebellar atrophy. Neurology, 27: 257-261.

PLAITAKIS, A., NICKLAS, W.J. and DESNICK, R.J. (1980). Glutamate dehydrogenase deficiency in three patients with spinocerebellar syndrome. Ann. Neurol., 7: 297-303.

ROBINSON, N. (1968). Chemical changes in spinal cord in Friedreich's Ataxia and motor neurone disease. J. Neurol. Neurosurg. Psychiat., 31: 330-333.

ROFFLER-TARLOV, S. and SIDMAN, R.L. (1978). Concentrations of glutamic acid in cerebellar cortex and deep nuclei of normal mice and weaver, staggerer and nervous mutants. Brain Res., 142: 269-293.

SCHMIDT, E. (1974). Glutamate dehydrogenase. in: Bergmeyer, H.V. "Methods in engymatic analysis".; Academic Press, New York, 2nd edition, pp. 650-656.

WASTIAUX, J.P., LAMOUREUX, G., BOUCHARD, J.P., DURIVAGE, A., BARBEAU, C. and BARBEAU, A. (1978). HLA and complement typing in olivoponto-cerebellar atrophy. Can. J. Neurol. Sci., 5: 75-81. 